\title{
Outplanting Performance of the Bornean Tropical Indigenous Species Shorea macrophylla (de Vriese) P. S. Ashton in relation to Seedling Age
}

\author{
Mugunthan Perumal $\mathbb{D}^{\mathbb{D}},{ }^{1,2}$ Mohd Effendi Wasli $\mathbb{D}^{\mathbb{D}},{ }^{1}$ and Soo Ying $\mathrm{Ho}(\mathbb{D})^{1,3}$ \\ ${ }^{1}$ Faculty of Resource Science and Technology, Universiti Malaysia Sarawak, 94300 Kota Samarahan, Sarawak, Malaysia \\ ${ }^{2}$ Institut Ekosains Borneo, Universiti Putra Malaysia Bintulu Sarawak Campus, P.O. Box 396, Nyabau Road, 97008 Bintulu, \\ Sarawak, Malaysia \\ ${ }^{3}$ Orchard House Sdn. Bhd., D-2-11, Miri Times Square, Marina Park City, 98000 Miri, Sarawak, Malaysia
}

Correspondence should be addressed to Mugunthan Perumal; mugunthanperumal89@gmail.com

Received 10 April 2020; Revised 29 April 2021; Accepted 5 May 2021; Published 20 May 2021

Academic Editor: Anna Zróbek-Sokolnik

Copyright (C) 2021 Mugunthan Perumal et al. This is an open access article distributed under the Creative Commons Attribution License, which permits unrestricted use, distribution, and reproduction in any medium, provided the original work is properly cited.

\begin{abstract}
Planting high-quality seedlings with desirable growth attributes are associated with successful survival and growth performance following outplanting. Considering that most tree species from the Dipterocarpaceae family are on the IUCN Red List of Threatened Species, proper conservation of such species is necessary. Very little is known with no clear consensus regarding whether increasing the seedling production period enhances outplanting survival and growth potential of tropical dipterocarp species planted under enrichment planting in Malaysia. In this study, one potential Bornean tropical indigenous species, Shorea macrophylla (de Vriese) P.S. Ashton, was produced in the Universiti Malaysia Sarawak nursery and outplanted at Sampadi Forest Reserve, Sarawak. Different nursery production periods (3, 6, 9, and 24 months) were tested for the species at the time of planting as well as for the subsequent growth performance after 12, 24, and 42 months of outplanting. The findings revealed that older (9and 24-month-old) S. macrophylla seedlings were morphologically larger from younger (3- and 6-month-old) seedlings. Nonetheless, the overall pooled mean survival rates declined from 61.7 to $44.6 \%$ after 12,24 , and 42 months of outplanting. For the 42-month period, the survival rate for the 9-month-old seedlings was significantly higher than that for the 3-, 6-, and 24-monthold seedlings. Notwithstanding, the relative growth rate of the stem diameter was higher for the 3-and 9-month-old seedlings than for the 6- and 24-month-old seedlings after 42 months of outplanting. Thus, maintaining plant material from the seedlings produced at 3,6, and 9 months of age would be beneficial for the initiation of transplantation in restoration programmes in Sarawak. The 24-month-old seedlings will also be useful, especially during irregular flowering and unpredictable fruiting intervals. A further experimental study on other environmental factors that could influence the outplanting performance of the seedlings in the tropical forest restoration area of Sarawak, Malaysia, is necessary.
\end{abstract}

\section{Introduction}

Seedling quality is a critical component in the successful implementation of forest restoration programmes [1]. Various previous studies have shown that age and size are two reliable, easy-to-use seedling quality indicators for field early performance [2]. According to Li et al. [3], by prolonging the cultivation period of seedlings in a nursery, i.e., by increasing the age of seedlings at the time of planting, larger seedlings may be produced. Larger seedlings usually perform better than smaller seedlings after planting $[4,5]$, especially under conditions of weed competition [6] and herbivorous vertebrate browsing [2]; however, decreasing survival with increasing seedling size has been detected at extremely harsh sites [7]. Grossnickle [8] specified that greater foliar mass of larger stocks allows increased photosynthetic efficiency, facilitating rapid growth and use of site resources during establishment. Nonetheless, a larger 
stock has higher carbohydrate storage and nutrients that can promote outplanting performance [9].

In addition, research undertaken in New Zealand, Scotland, South Africa, and the United States advocates the use of large-diameter stocks, which consistently perform better than small-diameter stocks, regardless of the silvicultural methods used [10]. However, these results are not applicable for all species, site conditions, and site preparation methods since the postplanting performance of a given species' large stock is likely to depend on the conditions of the reforestation site [3]. The actual growth performance of newly planted seedlings depends not only on the intrinsic performance potential of the seedlings (seedling quality) but also on the degree to which environmental conditions at a site allow for the expression of this potential [11].

Furthermore, the success of nurseries in producing highquality seedlings has not been fully investigated, and information on seedling performance after leaving nurseries for outplanting is needed [12]. Most of these previous studies focus on conifers from wet, temperate forests, with emphasis on nitrogen additions [13]. In addition, little is known about the factors that influence outplanting performance on the ability of tropical indigenous dipterocarp species from other ecoregions, particularly Malaysia, to withstand postplanting stress, and there is no consensus on the factors. Due to irregular flowering and unpredictable fruiting intervals in the tropics, several constraints on the production of dipterocarp seedlings have restricted the scale of reforestation programmes [14]. More than 70\% of emerging dipterocarp tree species from the Dipterocarpaceae family, which dominate South East Asia's tropical rain forests, are involved in mass flowering events but rarely reproduce in other years $[15,16]$.

Shorea macrophylla (de Vriese) P. S. Ashton is an endemic riparian species in the Dipterocarpaceae family, Southeast Asia's most important family of tropical rainforest trees [17]. It is considered one of the best indigenous tree species in Sarawak for tropical forest restoration and reforestation programmes and was chosen on the basis of its socioeconomic and ecological importance [18-21]. Under natural conditions in suitable areas, this canopy species can reach heights of $50 \mathrm{~m}$, diameters at breast height of $50-60 \mathrm{~cm}$ [22], and buttress heights of $2.0 \mathrm{~m}$ in the mixed dipterocarp forests of Sarawak and Brunei $[23,24]$. According to Lim et al. [25], S. macrophylla is a site-specific species and grows well (with a growth rate of $2.2 \mathrm{~cm}$ mean annual increment in diameter breast height) on clay alluvial soil of riparian forest and lower slopes of clay hills below $600 \mathrm{~m}$ above sea level. This lowland indigenous tree species is frequently found in wet habitats, such as rivers and periodically inundated areas, and is one of the fastest-growing species in the genus Shorea [19-21, 26-29]. S. macrophylla flowers sporadically in periods of mass flowering [30] and produces recalcitrant seeds with maximum viability of 1 month after collection [31]. In Tane' Ole Forest, North Kalimantan, Indonesia, this canopy species was found to show positive association or tolerance for cohabitation with Shorea borneensis, Eugenia spp., Palaquium spp., and Macaranga triloba [32]. S. macrophylla is considered a prime candidate for restoration efforts in humid tropical areas with poor soils due to its fast growth and hardiness.

Since research on seedling quality testing and field performance in Malaysia has received little attention, there is a need to evaluate the relationship between containerised seedling size as well as subsequent survival and field growth. This study was undertaken to identify attributes of seedling growth that ensure improved outplanting performance of S. macrophylla and to investigate the effects of seedling age on the subsequent survival, growth attributes, and biomass production. It is hoped that the socioeconomic and ecological importance of this species in the region will motivate nursery practitioners and forest managers to undertake enrichment planting in state forest reserves, which, in turn, justifies this study assessing seedling quality. Additionally, such seedling quality information could be used within the "target plant concept" to allow nursery practitioners, foresters, and land managers to engage in effective dialogue on how morphological seedling attributes will meet the goals of forest restoration. Although planting seedlings with desirable plant attributes after outplanting do not guarantee high survival and growth, planting seedlings with desirable attributes could increase the chances of a successful future forest restoration programme in Sarawak, Malaysia. In this study, we specifically addressed the following questions. (1) To what extent do S. macrophylla seedling survival and growth attributes (shoot height, stem diameter, total biomass, relative growth rate of shoot height, and stem diameter) differ in relation to the seedling age at outplanting? (2) Do these variations in seedling age at outplanting impact the survival and growth of outplanted field seedlings after 12, 24, and 42 months? These two questions will help to decide the optimal production period of seedlings in nurseries to achieve the desired morphological attributes, which will improve the early survival and growth of outplanted seedlings.

\section{Materials and Methods}

2.1. Seed Collection, Preparation of Growth Medium, and Seedling Production. For seedling production, seeds of S. macrophylla were collected randomly from three identified mother trees at Sampadi Forest Reserve, Lundu, Sarawak (N01 $34^{\prime} 13^{\prime \prime}, \mathrm{E} 109^{\circ} 53^{\prime} 12^{\prime \prime}$ ) (Figure 1), during a masting event, which began in late January-February 2015 [21]. Seedlings for three age groups (3-, 6-, and 9-month-old) were raised under the same conditions in the Universiti Malaysia Sarawak (UNIMAS) forest research nursery $\left(\mathrm{N} 01^{\circ} 27^{\prime} 820^{\prime \prime}, \mathrm{E} 110^{\circ} 27^{\prime} 079^{\prime \prime}\right)$ located in Kota Samarahan, Sarawak, Malaysia, from February to November 2015 (Figure 1). The existing 24-month-old seedlings were produced as bare-root seedlings from the same nursery with similar practices during the masting event in the year 2013 and were available as planting stocks in the nursery. During 2015 , the nursery received $2,898.0 \mathrm{~mm}$ of rain [33]. The monthly average air temperature and relative humidity were $27.0^{\circ} \mathrm{C}$ and $83.4 \%$, respectively [34]. On February 7, 2015, visibly healthy (i.e., free of fungus, decay, and herbivore damage) and uniformly sized seeds $(5.0-6.5 \mathrm{~cm}$ in length 


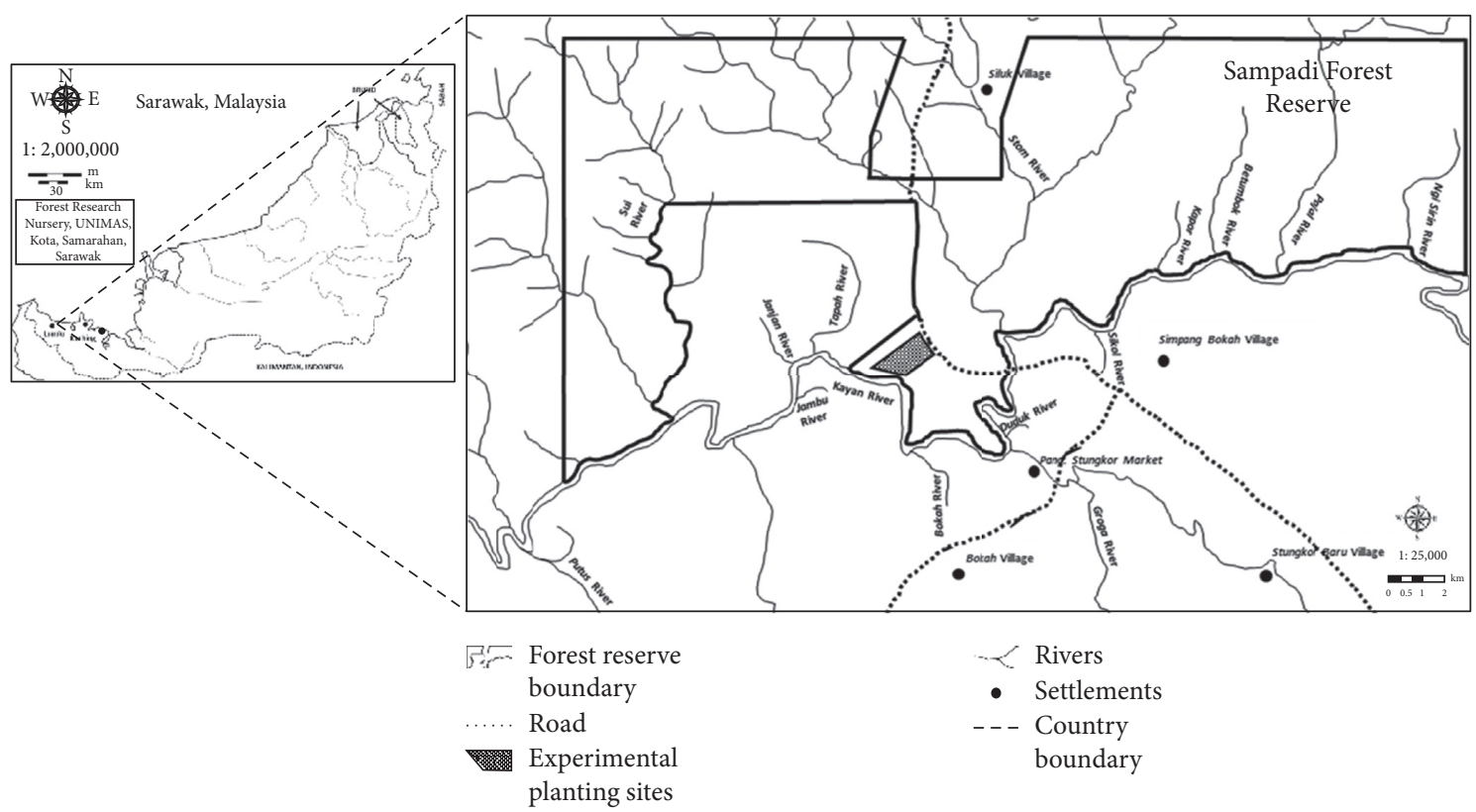

Figure 1: Location of the study area: Sampadi Forest Reserve Experimental Planting Sites. Perumal et al.; Mohamad Jaffar et al.; Department of Agriculture, Sarawak, Malaysia [19, 20, 27, 35].

and $2.5-4.0 \mathrm{~cm}$ in diameter) were selected, dewinged, and sown directly into black, perforated, polyethylene bags $(15.2 \mathrm{~cm}$ in diameter and $22.9 \mathrm{~cm}$ in depth) with several drainage holes at the bottom. The pots were filled with approximately $2.0 \mathrm{~kg}$ of a $1: 1$ mixture of topsoil and sand (v: $\mathrm{v}$ ), following the standard forest nursery practice for dipterocarp species in Sarawak [21]. Five grams of chemical fertilizer $(\mathrm{N}: \mathrm{P}: \mathrm{K}=10: 26: 10)$ per pot was applied as a top dressing of the polyethylene bags. The seedlings of the same cohorts were placed in bare ground under a white transparent net. To maintain optimum soil moisture, seedlings were watered once a day in the beginning and then as required. Hand weeding was performed regularly to prevent the growth of weeds on the surface of the polyethylene bags. Seedling production was designed in such a way that four seedling age groups (3-, 6-, 9-, and 24-month-old) were available at the time of transplanting. Since this was the first study to investigate the effects of seedling age on the outplanting performance of $S$. macrophylla, seedlings at 3, 6, 9, and 24 months old were selected for the purpose of this study.

2.2. Outplanting Site. Seedlings of S. macrophylla from all age groups were outplanted in 2015 at the Sampadi Forest Reserve Experimental Planting Sites (N01 03.953', E $\left.110^{\circ} 56.827^{\prime}\right)$, located approximately $72 \mathrm{~km}$ southwest of Kuching city in Lundu, Sarawak, Malaysia (Figure 1). The experimental site in the field was covered with grasses, shrubs, and pioneer trees. Therefore, prior to transplanting, most of the vegetation in each $5 \mathrm{~m}$ planting line was slashed, cut to ground level, and completely removed. Large pioneer species with the size of $35-40 \mathrm{~cm}$ diameter at breast height were left uncut when preparing the planting lines. The topography of the planting site is low and undulating with similar soil conditions, and the site has a humid seasonal subtropical climate in the wet forest biozone, with an average of more than $100 \mathrm{~mm}$ of precipitation over all months $[19,20,33,34,36,37]$. The rainfall was relatively uniform in this region throughout the year seedlings were outplanted. During 1995-2016, the study site received 3,361.4 mm of rain [33]. The monthly average air temperature and relative humidity were $26.3^{\circ} \mathrm{C}$ and $84.4 \%$, respectively, during 2010-2016 [34]. The major soil type in the planting site is derived from a mixture of sandstone, coarse-grained, and humult Ultisols, which generally have low fertility [18-20]. Based on the Sarawak soil classification system and our preliminary study in the area, the morphological characteristics of the soils resemble the Bako and Kayan soil series as a dominant unit in association with the Saratok series and are classified mainly in the soil group of Grey-White Podzolic soils interspersed with Red-Yellow Podzolic soils and Arenaceous soils $[18,35]$. According to the USDA-NRCS classification system, this soil group corresponds to Typic Paleaquults based on soil taxonomy [18, 38, 39]. The initial surface and subsurface soil physicochemical characteristics of the experimental planting sites are presented in Table 1.

2.3. Experimental Design and Outplanting of Seedlings. To investigate the effects of seedling age on the survival, growth attributes, and biomass production of $S$. macrophylla seedlings after 12,24, and 42 months of outplanting, the field experimental planting site was divided into three blocks separated by $5 \mathrm{~m}$, and each block was further divided into four plots of $50 \mathrm{~m} \times 10 \mathrm{~m}$, which were also separated from each other by $5 \mathrm{~m}$ strips. In each plot within each block, 20 seedlings of $S$. macrophylla from one age group $(3,6,9$, and 24 months) were planted at a $5 \mathrm{~m} \times 5 \mathrm{~m}$ spacing. During the layout planning for this experiment, in situ site conditions 
TABLE 1: Means and standard error of initial surface and subsurface soil physicochemical characteristics of the experimental planting sites at Sampadi Forest Reserve.

\begin{tabular}{|c|c|c|c|c|c|}
\hline \multirow{2}{*}{\multicolumn{2}{|c|}{$\begin{array}{l}\text { Soil depth/ } \\
\text { soil physicochemical properties }\end{array}$}} & \multicolumn{2}{|c|}{$0-10 \mathrm{~cm}$ (surface soils) } & \multicolumn{2}{|c|}{$30-40 \mathrm{~cm}$ (subsurface soils) } \\
\hline & & Mean \pm SE & (Min-Max.) & Mean \pm SE & (Min-Max.) \\
\hline $\mathrm{pH}\left(\mathrm{H}_{2} \mathrm{O}\right)$ & & $4.57 \pm 0.02$ & $(4.19-4.89)$ & $4.77 \pm 0.01$ & $(4.67-4.92)$ \\
\hline Total $\mathrm{C}^{\mathrm{a}}$ & $\left(\mathrm{g} \mathrm{kg}^{-1}\right)$ & $59.8 \pm 1.1$ & $(37.7-80.1)$ & $33.7 \pm 0.8$ & $(14.3-42.4)$ \\
\hline Total $\mathrm{N}^{\mathrm{b}}$ & $\left(\mathrm{g} \mathrm{kg}^{-1}\right)$ & $2.54 \pm 0.05$ & $(1.53-3.47)$ & $0.85 \pm 0.04$ & $(0.42-1.39)$ \\
\hline $\mathrm{CEC}^{\mathrm{c}}$ & $\left(\mathrm{cmol}_{\mathrm{c}} \mathrm{kg}^{-1}\right)$ & $18.6 \pm 0.3$ & $(10.4-23.2)$ & $15.6 \pm 0.4$ & $(7.0-19.2)$ \\
\hline Exch. $\mathrm{Ca}^{2+}$ & $\left(\mathrm{cmol}_{\mathrm{c}} \mathrm{kg}^{-1}\right)$ & $0.67 \pm 0.07$ & $(0.10-2.01)$ & $0.17 \pm 0.02$ & $(0.01-0.41)$ \\
\hline Exch. $\mathrm{Mg}^{2+}$ & $\left(\mathrm{cmol}_{\mathrm{c}} \mathrm{kg}^{-1}\right)$ & $0.69 \pm 0.04$ & $(0.24-1.36)$ & $0.12 \pm 0.01$ & $(0.04-0.29)$ \\
\hline Exch. $\mathrm{K}^{+}$ & $\left(\mathrm{cmol}_{\mathrm{c}} \mathrm{kg}^{-1}\right)$ & $0.20 \pm 0.02$ & $(0.01-0.57)$ & $0.14 \pm 0.02$ & $(0.01-0.49)$ \\
\hline Exch. $\mathrm{Al}^{3+}$ & $\left(\mathrm{cmol}_{\mathrm{c}} \mathrm{kg}^{-1}\right)$ & $2.77 \pm 0.13$ & $(1.33-4.69)$ & $3.13 \pm 0.09$ & $(2.26-4.66)$ \\
\hline Available P & $\left(\mathrm{mg} \mathrm{P} \mathrm{kg}{ }^{-1}\right)$ & $12.9 \pm 1.1$ & $(0.2-33.4)$ & $2.6 \pm 0.3$ & $(0.1-7.6)$ \\
\hline Clay & $(\%)$ & $51.8 \pm 0.8$ & $(28.0-60.2)$ & $49.2 \pm 1.0$ & $(23.4-58.2)$ \\
\hline Silt & $(\%)$ & $41.5 \pm 0.4$ & $(32.4-48.3)$ & $36.7 \pm 0.5$ & $(27.6-44.9)$ \\
\hline Sand & (\%) & $6.7 \pm 1.0$ & $(0.5-39.7)$ & $14.2 \pm 1.3$ & $(3.4-49.0)$ \\
\hline Bulk density & $\left(\mathrm{g} \mathrm{mL}^{-1}\right)$ & $0.86 \pm 0.01$ & $(0.72-1.04)$ & $1.17 \pm 0.02$ & $(0.86-1.53)$ \\
\hline
\end{tabular}

Means \pm standard error, ${ }^{\text {a }}$ Total C: total carbon; ${ }^{\mathrm{b}}$ Total N: total nitrogen; ${ }^{\mathrm{c}} \mathrm{CEC}$ : cation exchange capacity.

such as similar topography and existing vegetation were considered to ensure uniformity among the experimental sites for each seedling age treatment.

2.4. Data Collection and Analyses. The shoot height and stem diameter of all 60 seedlings from each age group were recorded one month after the transplantation. The measurements were repeated 12, 24, and 42 months after transplanting. Seedling shoot height and stem diameter were measured following the methods of Wasli et al. [40] and Perumal et al. [19]. Seedling shoot height from the root collar to the apical shoot tip was measured with a measuring tape and recorded to the nearest one decimal point in centimetres $(\mathrm{cm})$. Seedling stem diameter was measured at ten centimetres above ground level using a digital electronic caliper (Mitutoyo) and recorded to the nearest two decimal points in centimetres $(\mathrm{cm})$. The region on the stem was marked using a permanent marker as an indicator for subsequent monthly measurements for accuracy and consistency. Survival percentages were calculated as the number of seedlings of the original 20 that remained alive (in the first month) in each block and at the time of each measurement (12, 24, and 42 months after transplanting). The relative growth rate (RGR, hereafter) for shoot height and stem diameter in the field was calculated for 20 individuals in each age group using the following equation [41]:

$$
\mathrm{RGR}=\left(\frac{\operatorname{In} X_{2}-\operatorname{In} X_{2}}{\Delta t}\right),
$$

where $X_{1}$ and $X_{2}$ denote variables measured at the time of the first and second assessments, respectively, and $\Delta t$ is the time interval between the two measurements.

Prior to transplanting, the initial shoot, root, and total biomass, including the belowground biomass, of all 60 seedlings from each age group were quantified using allometric equations, and the formulas are as follows [42, 43]:

$$
\begin{aligned}
& \text { S. macrophylla: } Y=0.19 X^{1.05}, R^{2}=0.96 \text { where }\left[Y(g)=\text { shoot biomass, } X\left(\mathrm{~cm}^{3}\right)=\text { diameter }^{2} \times \text { height }\right] \text {, } \\
& \text { S. macrophylla: } Y=0.17 X^{0.82}, R^{2}=0.91 \text { where }\left[Y(g)=\text { root biomass, } X\left(\mathrm{~cm}^{3}\right)=\text { diameter }^{2} \times \text { height }\right] \text {, } \\
& \text { S. macrophylla: } Y=0.33 X^{0.99}, R^{2}=0.97 \text { where }\left[Y(g)=\text { total biomass, } X\left(\mathrm{~cm}^{3}\right)=\text { diameter }^{2} \times \text { height }\right] \text {. }
\end{aligned}
$$

The allometric equations were also used to quantify the shoot, root, and total biomass, including the belowground biomass, of the surviving $S$. macrophylla seedlings from each age group after 12,24 , and 42 months of outplanting in the field.

The data on seedling growth attributes at planting, seedling survival for the field experiment, and the outplanting trial were analysed using repeated-measures analysis of variance (ANOVA). For the purpose of statistical analyses, each individual seedling was treated as a replicate of the sampling unit, and the experimental unit was the mean response from the sampling units for each treatment replication. In each analysis, when ANOVA was significant, statistically significant differences between means were identified using Tukey's honestly significant difference (HSD) and Scheffe's multiple comparison tests. The interaction effect of seedling age and time of planting on the outplanting performance was done by repeated-measures analysis in General Linear Models (GLM). The coefficient of determination $\left(R^{2}\right)$ was calculated to quantify relationships among seedling age variables. All statistical analyses were performed using Statistical Package for the Social Sciences 
(SPSS) (IBM, version 24.0 for Windows) (Copyright: SPSS Inc., 2016).

\section{Results}

3.1. Performance of Outplanted Seedlings. The overall pooled mean survival rates declined from 61.7 to $44.6 \%$ after 12,24 , and 42 months of outplanting (Table 2). The survival rates of S. macrophylla seedlings varied and were affected by seedling age in the field. After 12 months of transplanting, seedling field survival ranged from 46.7 to $73.3 \%$ among the seedling ages. The survival rate at the 3 -month-old transplanting age was significantly higher $(P<0.05)$ than that at the 6-, 9-, and 24-month-old transplanting ages after 12 months of outplanting. However, there was no significant difference in survival rates between the 6- and 9-month-old transplanting ages after 12 months of outplanting. At 24 months after outplanting, the survival rates of the 3-, 6-, and 9-month-old transplanting seedlings were significantly higher than those of the 24-month-old seedlings. However, after 42 months of outplanting, the field survival rate of the 9-month-old seedlings was significantly higher (7.3-20.0\%) than that of the other seedlings. There was a significant month $\times$ age interaction effect observed for the survival rates of S. macrophylla seedlings after 12,24 , and 42 months of outplanting (Table 3).

Values are means \pm standard error; values in the same column followed by different letters indicate significant differences among seedling ages at 5\% level using Tukey's honestly significant difference (HSD) test.

Morphologically, almost all growth attributes and biomass production of $S$. macrophylla seedlings exhibited significant differences $(P<0.05)$ with respect to the period of nursery growth (Figure 2). The age at the time of transplanting affected shoot height $\left(F_{[3,236]}=466.503\right.$, $P<0.001)$, stem diameter $\left(F_{[3,236]}=73.069, P<0.001\right)$, total biomass $\left(F_{[3,236]}=155.155, P<0.001\right)$, and biomass allocation between the roots and shoots (root-to-shoot ratio) $\left(F_{[3,236]}=128.801, P<0.001\right)$.

The shoot height, stem diameter, and total biomass of the seedlings tended to increase with seedling age in the nursery and were significantly larger for the 24-month-old seedlings than for the 3-, 6-, or 9-month-old seedlings, except for the root-to-shoot ratio (Figure 2). However, the root-to-shoot ratio of the seedlings tended to decrease with increasing periods of nursery growth.

The 24-month-old seedlings maintained shoot height dominance after 12, 24, and 42 months of outplanting. Similarly, seedlings that were 6 and 9 months old maintained shoot height dominance after 12 and 24 months, while the differences declined after 42 months of outplanting (Figure 2(a)). For example, differences in seedling shoot height were significant between the 6- and 9-month-old seedlings after 12 and 24 months of transplanting, while no significant difference was found in the following 42 months after transplanting. Notwithstanding, there was no significant difference observed in shoot height between the 3 - and 6-month-old seedlings at 12, 24, and 42 months after outplanting. In general, shoot height tended to increase with
TABLE 2: Effect of seedling age on survival rate percentage of S. macrophylla seedlings after 12, 24, and 42 months of outplanting (mean \pm S.E).

\begin{tabular}{lccc}
\hline \multirow{2}{*}{ Seedling age } & \multicolumn{3}{c}{ Months after transplanting } \\
& 12 months & 24 months & 42 months \\
\hline 3-month & $73.3 \pm 2.1 \mathrm{c}$ & $63.3 \pm 1.7 \mathrm{~b}$ & $46.7 \pm 1.3 \mathrm{~b}$ \\
6-month & $61.7 \pm 0.8 \mathrm{~b}$ & $56.7 \pm 1.6 \mathrm{~b}$ & $45.0 \pm 1.8 \mathrm{~b}$ \\
9-month & $65.0 \pm 2.1 \mathrm{~b}$ & $60.0 \pm 2.4 \mathrm{~b}$ & $53.3 \pm 2.4 \mathrm{c}$ \\
24-month & $46.7 \pm 1.2 \mathrm{a}$ & $41.7 \pm 1.7 \mathrm{a}$ & $33.3 \pm 1.1 \mathrm{a}$ \\
Mean & 61.7 & 55.4 & 44.6 \\
\hline
\end{tabular}

seedling age, except for the 6-month-old seedlings in this study.

Relative to shoot height, younger (3- and 6-month-old) and older (24-month-old) seedlings lost their stem diameter dominance more rapidly (Figure 2(b)). As early as in the first 12 months of outplanting, no significant difference was shown in stem diameter between the 3- and 6-month-old seedlings (Figure 2(b)). Similarly, after 24 and 42 months, differences were not significant among the 3-, 6-, or 24month-old seedlings. The stem diameter was significantly higher and larger for the 9-month-old seedlings than that for the 6-and 24-month-old seedlings at 12 and 42 months after transplanting.

At 12 months after transplanting, the total biomass tended to increase with seedling age and was significantly greater for the 9- or 24-month-old seedlings than that for the 3- or 6-month-old seedlings (Figure 2(c)). However, at 24 and 42 months, significant differences were only found between the 6- and 24-month-old seedlings, as well as between the 6- and 9-month-old seedlings, respectively. The total biomass for the 9-month-old seedlings was larger than that of the other seedlings at 42 months after transplanting.

On the other hand, the biomass allocation of the seedlings between the roots and shoots, as determined by the root-to-shoot dry mass ratio after 12, 24, and 42 months of outplanting, varied significantly between the age groups (Figure 2(d)). The root-to-shoot ratio for the 9- and 24month-old transplanting ages was significantly lower than that for the 3-or 6-month-old transplanting ages after 12 months in the field (Figure 2(d)). The differences declined except for those between the 6-, 9-, or 24-month-old seedlings at 24 and 42 months after transplanting.

In terms of the RGR of shoot height, a significant difference was found in the first 12 months but not at 24 and 42 months after outplanting (Figure 2(e)). At 12 months after outplanting, the 9-month-old seedlings had a greater RGR in shoot height than that of the 3-month-old seedlings, followed by that of the 6-and 24-month-old seedlings. At the same time, a significant difference in the RGR of stem diameter was observed 12,24, and 42 months after outplanting (Figure 2(f)). At 12, 24, and 42 months after transplanting, the 3-month-old seedlings displayed a larger RGR in the stem diameter than that of the 9-month-old seedlings, followed by that of the 6- and 24-month-old seedlings.

Similar to survival rate, stem diameter, total biomass, root-to-shoot ratio, relative growth rates of shoot height, and stem diameter of S. macrophylla seedlings were found to 


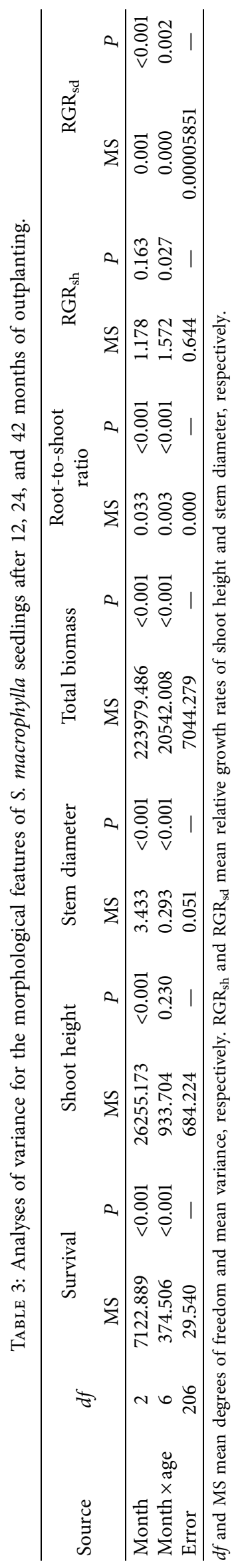




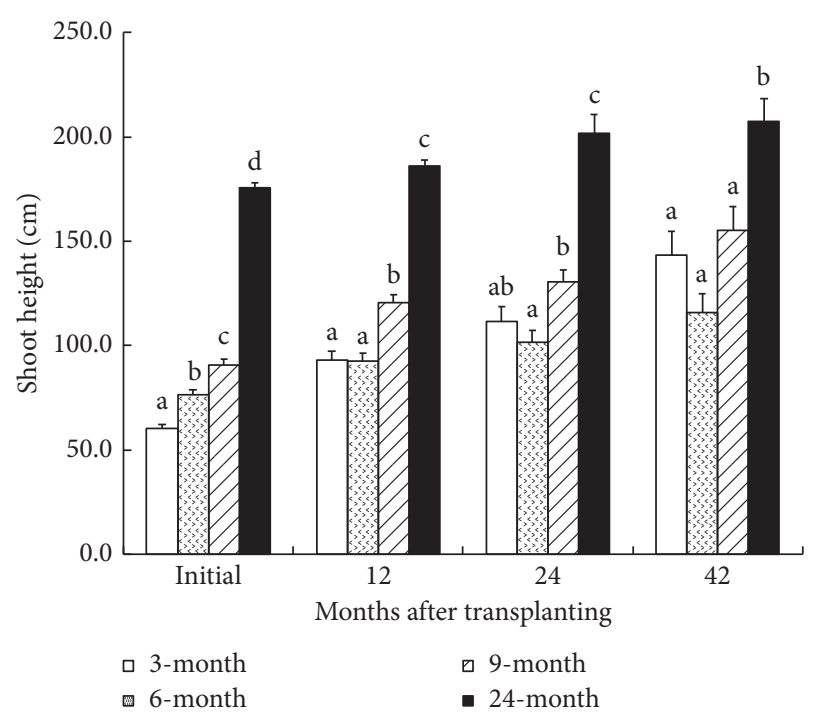

(a)

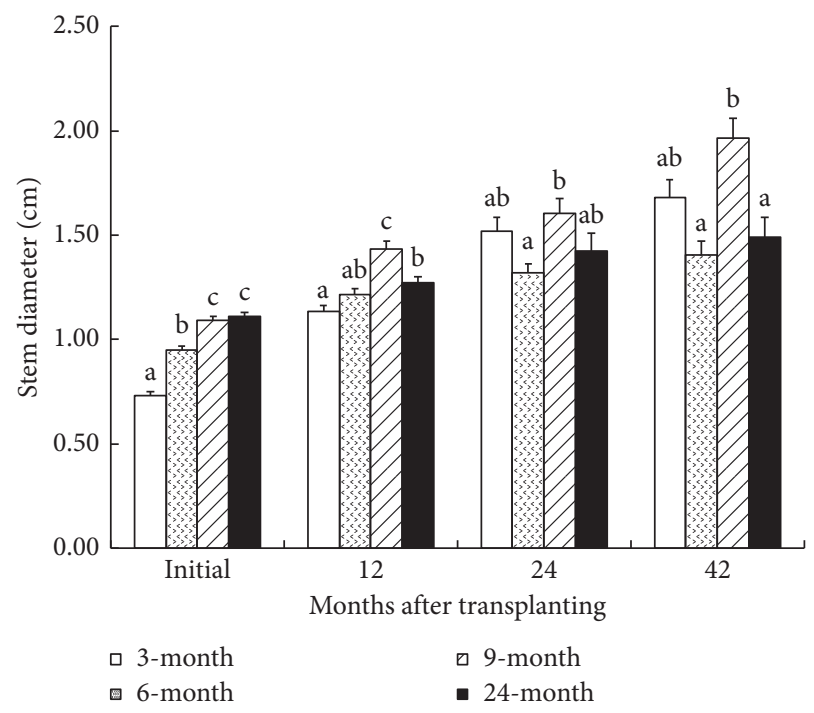

(b)
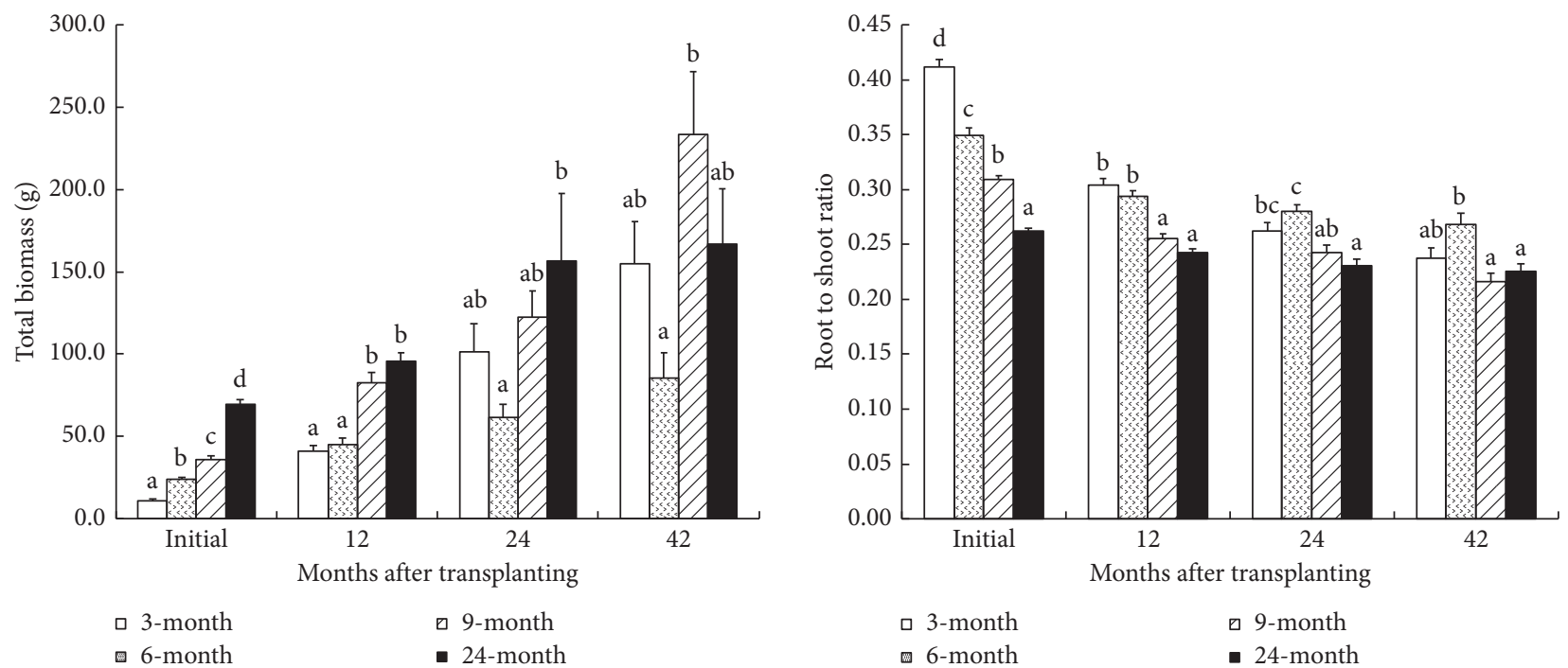

3-month

घ 9-month

- 6-month

- 24-month

- 24-month

(c)

(d)

Figure 2: Continued. 


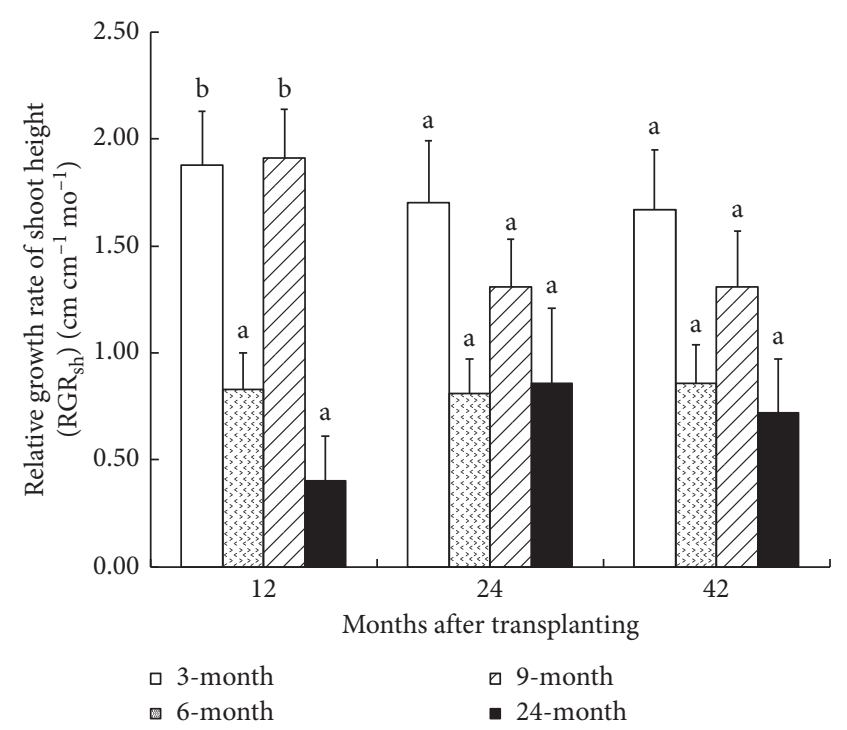

(e)

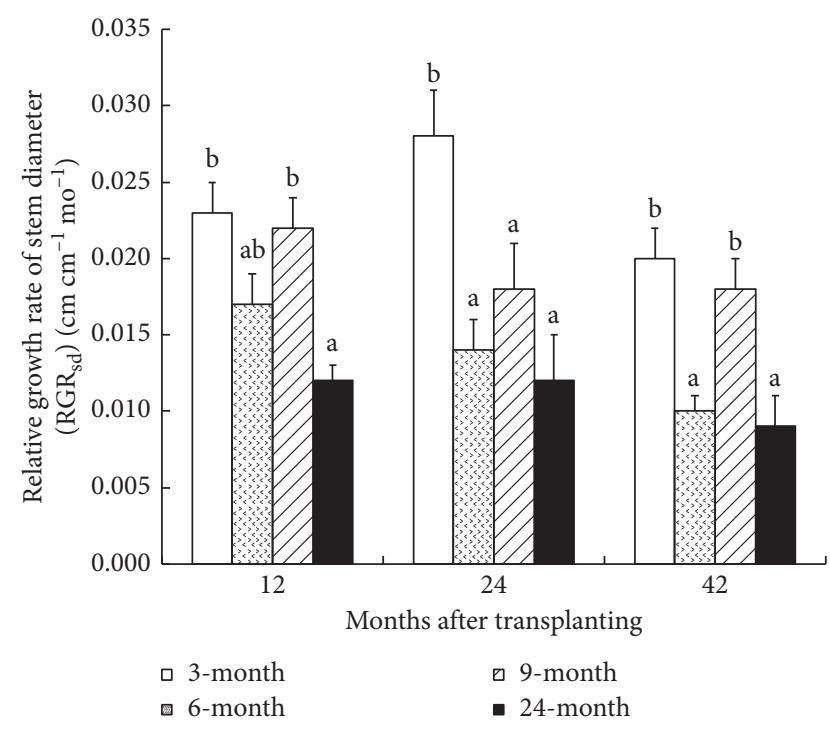

(f)

Figure 2: Initial seedling sizes of S. macrophylla differing in nursery age and effect of seedling age on (a) shoot height, (b) stem diameter, (c) total biomass, (d) root-to-shoot ratio, (e) relative growth rate of shoot height $\left(\mathrm{RGR}_{\mathrm{sh}}: \mathrm{cm} \mathrm{cm}^{-1} \mathrm{mo}^{-1}\right)$, and (f) relative growth rate of stem diameter $\left(\mathrm{RGR}_{\mathrm{sd}}: \mathrm{cm} \mathrm{cm}^{-1} \mathrm{mo}^{-1}\right)$ after 12,24 , and 42 months of outplanting. Bars are means and error bars are standard errors. Bars with different letters are significantly different at $5 \%$ level using Scheffe's multiple comparison test.

have significant month $\times$ age interaction effects after 12,24 , and 42 months of outplanting (Table 3 ). However, no significant month $\times$ age interaction effect was shown for shoot height in this study.

\section{Discussion}

4.1. Effects of Seedling Age on Survival after Outplanting. Under the conditions of this study, all morphological characteristics of the $S$. macrophylla seedlings varied significantly and exhibited a response to seedling age (young and old seedlings) at planting (Figure 2). Since the production of high-quality seedlings in a reasonable period is the ultimate goal desired by nursery personnel, improvements to current nursing practices such as the lack of mycorrhizal inoculation in order to produce seedlings with the appropriate morphological and physiological attributes are necessary for improved field performance [44].

Following the first 12 and 24 months after outplanting at the Sampadi Forest Reserve experimental sites, field survival was considered moderately high for the 3-, 6-, and 9-monthold nursery age groups but was slightly low for the 24month-old nursery age group (Table 2). However, at 42 months after outplanting, the 9-month-old seedling group had the highest survival rate compared to that of the other nursery age groups. This higher survival rate of 9-month-old seedlings could be associated with having more developed roots as compared to other nursery age groups in this study. A previous long-term monitoring study by Hattori et al. [43] in Niah Forest Reserve, Sarawak, recorded that $43.9 \%$ and $52.3 \%$ of 12 -month-old S. macrophylla seedlings survived in secondary and logged forests after 81 months of outplanting, respectively. Notwithstanding, higher survival is usually reported in seedlings planted under secondary and logged forests; for example, $37.5 \%$ to $70.0 \%$ of Shorea parvifolia seedlings were alive after 24 months in Indonesian secondary forests where line planting techniques have been used [45], and more than $94 \%$ of Dryobalanops aromatica and S. parvifolia seedlings survived after 22 months in a secondary forest of Sampadi Forest Reserve and Balai Ringin Protected Forest in Sarawak [36]. In contrast, the high survival of $S$. parvifolia recorded in previous studies may have subsequently declined after more than 2 years of outplanting since only $11.8 \%$ and $25.7 \%$ of the seedlings remained 81 months after outplanting in the secondary and logged forests of Niah Forest Reserve, respectively [43]. Nevertheless, survival in the field was generally high for nursery age groups of 3,6, and 9 months, possibly due to the protection of the polybag (container) as well as the degree of disruption to the root system during storage, lifting, transportation, and planting, which is significantly lower for container-grown seedlings than bare-root seedlings $[44,46,47]$. Therefore, container-grown seedlings experience lower plant water stress after transplantation compared to J-root or bare-rooted seedlings (24-month-old seedlings) and have improved survival in the field. In contrast, a degree of disruption to the root system during storage, lifting, transportation, and planting probably resulted in a low survival rate for the 24 -month-old seedlings. For this research, the field survival rate of the 6-month-old seedlings was apparently much lower than that of the 3-and 9-monthold seedlings and rapidly decreased (Table 2), which probably caused the mortality of the planted seedlings due to site-specific environmental factors [48]. Studies by Garau et al. [49] indicated that small seedlings are more prone and sensitive to site environments and site preparation. 
However, in the case of this study, it is unclear that 6-monthold seedlings had a lower survival rate than that of the 3month-old seedlings following the justification of Garau et al. [49] that smaller seedlings are more vulnerable to site environments and site preparation including transplanting shock. A large mass $[50,51]$ can promote the field performance of seedlings. This could explain why, in comparison to the other seedlings, the 9-month-old seedlings with higher total biomass (Figure 2(c)) in this study had greater longterm survival after 42 months of outplanting (Table 2 ).

\subsection{Effects of Seedling Age on Growth after Outplanting.} In terms of growth attributes, younger (3- and 6-month-old) and older (9- and 24-month-old) seedlings of S. macrophylla were different at the time of planting (Figure 2). Nonetheless, these variations in seedling sizes at the time of planting still persisted in the field after 12, 24, and 42 months of outplanting for all seedling growth attributes, except for variation in seedling ages for the relative growth rate of shoot height after 24 and 42 months (Figure 2). Although there were no significant differences, it does appear that the 3 - and 9-month-old seedlings have the highest shoot growth rates across the 12- to 42-month range, and the ability to detect differences in RGR could be limited by the small sample size of seedlings planted in this study as growth rates are highly variable. For the 3-month-old seedlings, a higher RGR in both shoot height and stem diameter was found after outplanting (Figures 2(e) and 2(f)). A possible explanation is that small seedlings experienced less transplant shock when outplanted [16, 52], or small seedlings displayed higher photochemical activity potential when established [51]. Considering field performance, 3-month-old seedlings have shorter culture periods in the nursery and are easier to handle for planting because of their small size. Thus, the seedlings can be kept as planting material in the nursery for reforestation programmes, especially during irregular flowering or unpredictable fruiting intervals of S. macrophylla. A previous study by Hattori et al. [43] in Niah Forest Reserve reported that $S$. macrophylla seedlings had a relatively lower growth rate for height $\left(0.105 \mathrm{~cm} \mathrm{~cm}^{-1}\right.$ year $\left.^{-1}\right)$ and diameter $\left(0.124 \mathrm{~mm} \mathrm{~mm}^{-1}\right.$ year $\left.^{-1}\right)$ than that of Dryobalanops beccarii $\left(0.316 \mathrm{~cm} \mathrm{~cm}^{-1} \mathrm{year}^{-1}\right.$ and $0.328 \mathrm{~mm} \mathrm{~mm}^{-1}$ year $^{-1}$, respectively), $S$. parvifolia $\left(0.328 \mathrm{~cm} \mathrm{~cm}^{-1}\right.$ year $^{-1}$ and $0.308 \mathrm{~mm} \mathrm{~mm}^{-1}$ year $\left.^{-1}\right)$, and other Shorea species. In open areas of Borneo, the tree height growth of planted dipterocarp species such as $S$. macrophylla (461 cm after 72 months) [53], S. ovata $(450 \mathrm{~cm}$ after 60 months) [54], and 11 other dipterocarp species (320 to $580 \mathrm{~cm}$ after 60 months) [55] was also reported.

Based on this study, a relatively higher RGR in shoot height and stem diameter for the 9-month-old seedlings after outplanting was also found, calling into question the conventional recommendation that larger seedlings make the best planting stock $[56,57]$. The older and larger 24month-old bare-root seedlings could be useful as well for planting stock in this study. In many studies, in comparison to smaller seedlings, larger seedlings tend to maintain a size advantage over time $[58,59]$, partly due to the ability to outgrow competing vegetation [56], while others report that differences decrease after a few years $[60,61]$. In addition, the general pattern found in this and other studies has also been that when seedlings with large diameters are properly planted (morphologically improved), they usually grow better than smaller seedlings $[56,62]$. It can be deduced that seedling performance is diameter related and seedlings with large diameters tend to survive and grow better than seedlings with a small diameter [57, 62]. According to Simpson and Ritchie [63], one reason that larger seedlings display greater growth is that the large seedlings produce more roots soon after planting.

In this study, we found that the biomass allocation pattern in both of the younger and older S. macrophylla seedlings favoured the general requirements of a balanced and healthy root system (root-to-shoot dry mass ratio $<2.0 \mathrm{~g} / \mathrm{g}$ ) [21] and continued to sustain this pattern in the field (Figure 2). In general, these seedlings typically had higher growth potential and were able to withstand adverse conditions (periodic inundation) at the planting sites due to the adequate root system that did not hinder plant growth. Although we did not measure this result, we observed shoot dieback of seedlings due to the flooding effect that occurred in January 2016. In certain instances, a high root-to-shoot ratio is beneficial for seedling growth. For example, under conditions where a wet season precedes a dry summer, seedlings described as productive phenotypes (i.e., large seedlings with high root-to-shoot ratios and fertility) have a relatively higher growth potential [21, 61], with larger seedlings being better established during the wet season $[64,65]$.

To develop a practical technique for ensuring an improved field performance of S. macrophylla seedlings for forest restoration purposes, the results from this study suggest that 3-, 6-, and 9-month-old seedlings should be kept as planting material before transplantation is initiated in Sarawak restoration programmes [21]. In several cases, dipterocarp seedlings will have to be maintained over a much longer period of time before transplantation, depending on the restoration programmes [66]. In that case, the 24-month-old seedling will be useful as well as during irregular flowering and unpredictable fruiting intervals of S. macrophylla. A previous study by Irino et al. [66] concluded that Dryobalanops lanceolata seedlings from the Dipterocarpaceae family display sound growth without additional fertilization, even though the seedlings were maintained in the nursery for 18 months after the application of controlled-release fertilizer (CRF).

\section{Conclusions and Recommendations}

In conclusion, the present study found that all growth attributes of the $S$. macrophylla seedlings differed in relation to the seedling age. The seedling age (3-, 6-, 9-, and 24-monthold) at the time of planting affected the survival rate of the transplanted seedlings. Nonetheless, the relative growth rate of stem diameter was significantly higher for the 3- and 9month-old seedlings than the 6- and 24-month-old seedlings after 42 months of outplanting. In this study, biomass 
production for the 9-month-old seedlings was the greatest at 42 months after transplanting. We also conclude that seedlings produced at 3,6 , and 9 months of age should be maintained as planting material for the initiation of transplantation in restoration programmes in Sarawak. The 24month-old seedlings will be useful, especially during irregular flowering and unpredictable fruiting intervals of S. macrophylla in the tropics. As a follow-up to this study, a further experimental study on other environmental factors that could influence the outplanting performance of seedlings in the tropical forest restoration area of Sarawak, Malaysia, is necessary. Other follow-up studies that would be helpful, and that could be done with the existing experiment, are to monitor reproduction in terms of fruiting and flowering or to do harvests to better quantify above- and belowground biomass of $S$. macrophylla seedlings. A good understanding of the interaction between seedling morphological and physiological status and how this affects survival and growth in the field is required. In addition, a long-term monitoring period is needed to develop a solid conclusion across various experimental treatments, site conditions, and species. It is hoped that all the scientific information and findings from this study would be very useful as guidelines for forest managers, nursery practitioners, and policymakers to initiate and undertake enrichment planting in the state forest reserves as they meet the forest restoration set standards.

\section{Data Availability}

The data that support the findings of this study are available from the corresponding author upon reasonable request.

\section{Disclosure}

The research project was conducted under the supervision of Dr. Mohd Effendi Wasli, and the project was run as Mugunthan Perumal's research project.

\section{Conflicts of Interest}

The authors declare that there are no conflicts of interest regarding the publication of this paper.

\section{Acknowledgments}

The authors wish to express gratitude to the Director and staff of the Forest Department, Sarawak, for their supportive assistance during this study. The authors would also like to thank local villagers, especially Mr. Jebeng, for their kind cooperation and assistance during the field survey. This study was financially supported by the Grant-in-Aid for scientific research purpose by the Japan-Malaysia Association (JMA).

\section{References}

[1] S. Grossnickle and J. MacDonald, "Seedling quality: history, application, and plant attributes," Forests, vol. 9, no. 5, pp. 283-305, 2018.
[2] D. C. Close, S. Paterson, R. Corkrey, and C. McArthur, "Influences of seedling size, container type and mammal browsing on the establishment of Eucalyptus globulus in plantation forestry," New Forests, vol. 39, no. 1, pp. 105-115, 2010.

[3] G. L. Li, Y. Liu, Y. Zhu et al., "Influence of initial age and size on the field performance of Larix olgensis seedlings," New Forests, vol. 42, no. 2, pp. 215-226, 2011.

[4] D. B. South, M. I. Menzies, and D. Grant Holden, "Stock size affects outplanting survival and early growth of fascicle cuttings of Pinus radiata," New Forests, vol. 29, no. 3, pp. 273-288, 2005.

[5] B. Cuesta, P. Villar-Salvador, J. Puértolas, D. F. Jacobs, and J. M. Rey Benayas, "Why do large, nitrogen rich seedlings better resist stressful transplanting conditions? A physiological analysis in two functionally contrasting Mediterranean forest species," Forest Ecology and Management, vol. 260, no. 1, pp. 71-78, 2010.

[6] D. B. South and R. J. Mitchell, "Determining the "optimum" slash pine seedling size for use with four levels of vegetation management on a flatwoods site in Georgia, U.S.A," Canadian Journal of Forest Research, vol. 29, no. 7, pp. 1039-1046, 1999.

[7] J. Puértolas, D. F. Jacobs, L. F. Benito, and J. L. Peñuelas, "Cost-benefit analysis of different container capacities and fertilization regimes in Pinus stock-type production for forest restoration in dry Mediterranean areas," Ecological Engineering, vol. 44, pp. 210-215, 2012.

[8] S. C. Grossnickle, Ecophysiology of Northern Spruce Species. The Performance of Planted Seedlings, NRC Research Press, Ottawa, Canada, 2000.

[9] J. A. Oliet, R. Planelles, F. Artero, R. Valverde, D. F. Jacobs, and M. L. Segura, "Field performance of Pinus halepensis planted in Mediterranean arid conditions: relative influence of seedling morphology and mineral nutrition," New Forests, vol. 37, no. 3, pp. 313-331, 2009.

[10] D. B. South, R. J. Mitchell, B. R. Zutter et al., "Integration of nursery practices and vegetation management: economic and biological potential for improving regeneration," Canadian Journal of Forest Research, vol. 23, no. 10, pp. 2083-2092, 1993.

[11] R. S. Folk and S. C. Grossnickle, "Determining field performance potential with the use of limited environmental conditions," New Forests, vol. 13, pp. 121-138, 1996.

[12] A. Degrande, P. Tadjo, B. Takoutsing, E. Asaah, A. Tsobeng, and Z. Tchoundjeu, 'Getting Trees Into Farmers' Fields: Success of Rural Nurseries in Distributing High Quality Planting Material in Cameroon," Small-scale Forestry, vol. 12, no. 3, pp. 403-420, 2012.

[13] S. Jose, S. Merritt, and C. L. Ramsey, "Growth, nutrition, photosynthesis and transpiration responses of longleaf pine seedlings to light, water and nitrogen," Forest Ecology and Management, vol. 180, no. 1, pp. 335-344, 2003.

[14] H. Aminah, J. M. Dick, R. R. B. Leakey, J. Grace, and R. I. Smith, "Effect of indole butyric acid (IBA) on stem cuttings of Shorea leprosula," Forest Ecology and Management, vol. 72, no. 2-3, pp. 199-206, 1995.

[15] S. Sakai, K. Momose, T. Yumoto et al., "Plant reproductive phenology over four years including an episode of general flowering in a lowland dipterocarp forest, Sarawak, Malaysia," American Journal of Botany, vol. 86, no. 10, pp. 1414-1436, 1999.

[16] T. Ichie and M. Nakagawa, "Dynamics of mineral nutrient storage for mast reproduction in the tropical emergent tree 
Dryobalanops aromatica," Ecological Research, vol. 28, no. 2, pp. 151-158, 2013.

[17] S. Utomo, K. Uchiyama, S. Ueno et al., "Effects of Pleistocene climate change on genetic structure and diversity of Shorea macrophylla in Kalimantan rainforest," Tree Genetics and Genomes, vol. 14, p. 44, 2018.

[18] M. Perumal, M. E. Wasli, S. Y. Ho, J. Lat, and H. Sani, "Soil morphological and physicochemical properties at reforestation sites after enrichment planting of Shorea macrophylla in Sampadi Forest Reserve, Sarawak, Malaysia,” Borneo Journal of Resource Science and Technology, vol. 5, no. 2, pp. 28-43, 2015.

[19] M. Perumal, M. E. Wasli, S. Y. Ho, J. Lat, and H. Sani, "Survivorship and growth performance of Shorea macrophylla (de Vriese) after enrichment planting for reforestation purpose at Sarawak, Malaysia," OnLine Journal of Biological Sciences, vol. 17, no. 1, pp. 7-17, 2017.

[20] M. Perumal, M. E. Wasli, S. Y. Ho, J. Lat, and H. Sani, "Association between soil fertility and growth performance of planted Shorea macrophylla (de Vriese) after enrichment planting at rehabilitation sites of Sampadi Forest Reserve, Sarawak, Malaysia," International Journal of Forestry Research, vol. 2017, Article ID 6721354, 16 pages, 2017.

[21] M. Perumal, M. E. Wasli, and S. Y. Ho, "Influences of inorganic and organic fertilizers to morphological quality attributes of Shorea macrophylla seedlings in a tropical nursery," Biodiversitas Journal of Biological Diversity, vol. 20, no. 8, pp. 2110-2118, 2019.

[22] M. F. Newman, P. F. Burgess, and T. C. Whitmore, Borneo Island Light Hardwood-Manual of Dipterocarps for Foresters, CIFOR, Bogor, Indonesia, 1996.

[23] P. S. Ashton, Ecological Studies in the Mixed Dipterocarp Forests of Brunei State, Clarendon Press, Oxford, UK, 1st edition, 1964.

[24] P. S. Ashton, Dipterocarpaceae. Flora Malesiana Ser I., Vol. 9Springer, Berlin, Heidelberg, 1982.

[25] N. P. T. Lim, Y. E. Tan, K. S. Gan et al., Shorea macrophylla (Engkabang jantong) Planted in Sarawak: ITTO Project on Improving Utilization and Value Adding of Plantation Timbers from Sustainable Sources in Malaysia Project No. PD 306/04 (1), vol.1, Forest Research Institute Malaysia, Kula lumpur, Malaysia, 2011.

[26] P. S. Ashton, "Shorea macrophylla. The IUCN red list of threatened species," 1998.

[27] A. N. N. Mohamad Jaffar, M. E. Wasli, M. Perumal, J. Lat, and H. Sani, "Effects of soil compaction and relative light intensity on survival and growth performance of planted Shorea macrophylla (de Vriese) in riparian forest along Kayan Ulu River, Sarawak, Malaysia," International Journal of Forestry Research, vol. 2018, Article ID 6329295, 11 pages, 2018.

[28] A. N. N. Mohamad Jaffar, M. E. Wasli, and M. Perumal, "Evaluation on soil hardness in riparian forest restoration along Kayan Ulu River, Sarawak, Malaysia," Trends in Undergraduate Research, vol. 1, no. 1, pp. a33-39, 2018.

[29] A. N. N. Mohamad Jaffar, M. E. Wasli, M. Perumal, H. Sani, and J. Lat, "Assessment of soil hardness expressed by one drop penetrability at forest restoration sites along Kayan Ulu River, Sarawak, Malaysia," in Proceedings of the Translating Applied Biology For Future Sustainability: The 15th Symposium Of Malaysian Society Of Applied Biology, pp. 28-35, Melaka, Malaysia, November 2018.

[30] S. Appanah and G. Weinland, Planting Quality Timber Trees In Peninsular Malaysia-Review, Malaysian Forest Record No.
38, Forest Research Institute Malaysia, Kuala lumpur, Malaysia, 1993.

[31] F. S. P. Ng, "Gregarious flowering of dipterocarps in Kepong," Malaysian Forester, vol. 40, pp. 126-137, 1976.

[32] M. Fajri, Pratiwi, and Y. Ruslim, "The characteristics of Shorea macrophylla's habitat in Tane' Olen, Malinau District, North Kalimantan Province, Indonesia," Biodiversitas Journal of Biological Diversity, vol. 21, no. 8, pp. 3454-3462, 2020.

[33] Drainage and Irrigation Department, Weather Data (Rainfall) 1995-2016, Drainage and Irrigation Department, Kuching, Malaysia, 2017.

[34] Meteorological Department, Weather Data (Surface Air Temperature and Relative Humidity) 2010-2016, Meteorological Department, Kuching, Malaysia, 2017.

[35] Department of Agriculture Sarawak, Soil Map, Department of Agriculture, Kuching, Sarawak, Malaysia, 2018.

[36] A. Vincent and S. J. Davies, "Effects of nutrient addition, mulching and planting-hole size on early performance of Dryobalanops aromatica and Shorea parvifolia planted in secondary forest in Sarawak, Malaysia," Forest Ecology and Management, vol. 180, no. 1, pp. 261-271, 2003.

[37] M. Perumal, M. E. Wasli, and J. Lat, "Effects of enrichment planting on the soil physicochemical properties at reforestation sites planted with Shorea macrophylla de Vriese in Sampadi Forest Reserve, Sarawak, Malaysia," in Proceedings of the International Symposium on Frontier in Tropical Forest Research: Progress in Joint Projects between the Forest Department Sarawak and the Japan Research Consortium for Tropical Forests in Sarawak, pp. 19-29, Forest Department Sarawak (FDS) and Japan Research Consortium for Tropical Forests in Sarawak (JRCTS), Kuching, Malaysia, June 2016.

[38] S. C. Teng, Keys to Soil Classification of Sarawak, Agriculture Department of Sarawak, Kuching, Malaysia, 2004.

[39] Soil Survey Staff, Keys to Soil Taxonomy, United States Department of Agriculture and Natural Resources Conservation Service, Washington, DC, USA, 12th edition, 2014.

[40] M. E. Wasli, H. Sani, S. Y. Ho et al., "Preliminary assessment on the growth performance of Dryobalanops beccarii Dyer planted under enrichment planting technique at Gunung Apeng Forest Reserve, Sarawak, Malaysia," Kuroshio Science, vol. 8, no. 1, pp. 45-52, 2014.

[41] P. J. Kramer and T. T. Kozlowski, Physiology of Woody Plants, Academic Press, New York, NY, USA, 1979.

[42] T. Kenzo, "Studies on ecophysiological properties related to photosynthesis of dipterocarpaceae in tropical rainforest of Sarawak," Ph. D. Thesis, Ehime University, Matsuyama, Japan, 2004.

[43] D. Hattori, K. Tanaka, J. J. Kendawang, N. Ikuo, and S. Katsutoshi, "Rehabilitation of degraded tropical rainforest using dipterocarp trees in Sarawak, Malaysia," International Journal of Forestry Research, vol. 2013, Article ID 683017, 11 pages, 2013.

[44] D. Zida, M. Tigabu, L. Sawadogo, and P. C. Odén, "Initial seedling morphological characteristics and field performance of two Sudanian savanna species in relation to nursery production period and watering regimes," Forest Ecology and Management, vol. 255, no. 7, pp. 2151-2162, 2008.

[45] G. Adjers, S. Hadengganan, J. Kuusipalo, K. Nuryanto, and L. Vesa, "Enrichment planting of dipterocarps in logged-over secondary forests: effect of width, direction and maintenance method of planting line on selected Shorea species," Forest Ecology and Management, vol. 73, no. 1-3, pp. 259-270, 1995.

[46] Y. Liu, Seedlings Quality Control Theory and Technology, Chinese Forestry Press, Beijing, China, 1999. 
[47] E. R. Wilson, K. C. Vitols, and A. Park, "Root characteristics and growth potential of container and bare-root seedlings of red oak (Quercus rubra L.) in Ontario, Canada," New Forests, vol. 34, no. 2, pp. 163-176, 2007.

[48] K. L. Hitch, B. D. Shiver, and B. E. Borders, "Mortality models for newly regenerated loblolly pine plantations in the Georgia Piedmont," Southern Journal of Applied Forestry, vol. 20, no. 4, pp. 197-202, 1996.

[49] A. M. Garau, C. M. Ghersa, J. H. Lemcoff, and J. J. Barañao, "Weeds in Eucalyptus globulus subsp. maidenii (F. Muell) establishment: effects of competition on sapling growth and survivorship," New Forests, vol. 37, no. 3, pp. 251-264, 2009.

[50] K. Johansson, U. Nilsson, and H. Lee Allen, "Interactions between soil scarification and Norway spruce seedling types," New Forests, vol. 33, pp. 13-27, 2007.

[51] F. Renou-Wilson, M. Keane, and E. P. Farrell, "Effect of planting stocktype and cultivation treatment on the establishment of Norway spruce on cutaway peatlands," New Forests, vol. 36, no. 3, pp. 307-330, 2008.

[52] D. C. Close and C. L. Beadle, "Cold-induced photoinhibition, nutrition and growth analysis of Eucalyptus nitens (Deane and Maiden) maiden seedlings during establishment," Tree Physiology, vol. 23, no. 4, pp. 217-226, 2003.

[53] H. S. Lee, A. Itoh, M. Kanzaki, and T. Yamakura, "Height growth of Engkabang Jantong, Shorea macrophylla (De Vr.) Ashton, in a plantation forest in Sarawak," Tropics, vol. 7, pp. 67-80, 1997.

[54] M. A. Alias, M. Z. Hamzah, K. Fujiwara, and S.-i. Meguro, "Rehabilitation of tropical rainforests based on potential natural vegetation species for degraded areas in Sarawak, Malaysia," Tropics, vol. 7, pp. 223-239, 1998.

[55] S. I. Meguro and A. Miyawaki, "A study of initial growth behaviour of planted Dipterocarpaceae trees for restoration of tropical rain forests in Borneo/Malaysia," Tropical Ecology, vol. 38, pp. 237-245, 1997.

[56] D. B. South, S. W. Harris, J. P. Barnett, M. J. Hainds, and D. H. Gjerstad, "Effect of container type and seedling size on survival and early height growth of Pinus palustris seedlings in Alabama, U.S.A," Forest Ecology and Management, vol. 204, no. 2-3, pp. 385-398, 2005.

[57] D. A. McGrath and M. L. Duryea, "Initial moisture stress, budbreak and two-year field performance of three morphological grades of slash pine seedlings," New Forests, vol. 8, pp. 335-350, 1994.

[58] R. Rose and J. Scott Ketchum, "Interaction of initial seedling diameter, fertilization and weed control on Douglas-Fir growth over the first four years after planting," Annals of Forest Science, vol. 60, no. 7, pp. 625-635, 2003.

[59] D. L. Haase, R. Rose, and J. Trobaugh, "Field performance of three stock sizes of Douglas-Fir container seedlings grown with slow-release fertiliser in the nursery growing medium," New Forests, vol. 31, no. 1, pp. 1-24, 2006.

[60] D. B. South, J. L. Rakestraw, and G. A. Lowerts, "Early gains from planting large-diameter seedlings and intensive management are additive for loblolly pine," New Forests, vol. 22, pp. 97-110, 2001.

[61] J. A. Oliet, R. Planelles, F. Artero, and D. Jacobs, "Nursery fertilization and tree shelters affect long-term field response of Acacia salicina Lindl. planted in Mediterranean semiarid conditions," Forest Ecology and Management, vol. 215, no. 1-3, pp. 339-351, 2005.

[62] D. B. South, J. B. Zwolinski, and D. G. M. Donald, "Interactions among seedling diameter grade, weed control, and soil cultivation for Pinus radiata in South Africa," Canadian
Journal of Forest Research, vol. 23, no. 10, pp. 2078-2082, 1993.

[63] D. G. Simpson and G. A. Ritchie, "Does RGP predict field performance? A debate," New Forests, vol. 13, no. 1-3, pp. 253-277, 1997.

[64] P. Villar-Salvador, J. Puértolas, B. Cuesta et al., "Increase in size and nitrogen concentration enhances seedling survival in Mediterranean plantations. Insights from an ecophysiological conceptual model of plant survival," New Forests, vol. 43, no. 5-6, pp. 755-770, 2012.

[65] P. Villar-Salvador, M. Uscola, and D. F. Jacobs, "The role of stored carbohydrates and nitrogen in the growth and stress tolerance of planted forest trees," New Forests, vol. 46, no. 5-6, pp. 813-839, 2015.

[66] K. O. Irino, Y. Kang, K. T. Kenzo et al., "Performance of potgrown seedlings of the dipterocarp Dryobalanops lanceolata with controlled-release fertilizer after transplantation to the shifting cultivation land in Sarawak, Malaysia," Soil Science and Plant Nutrition, vol. 51, no. 3, pp. 369-377, 2005. 